\title{
Vertical Distribution of a Soil Microbial Community as Affected by Plant Ecophysiological Adaptation in a Desert System
}

\author{
G. Barness • S. Rodriguez Zaragoza • I. Shmueli • \\ Y. Steinberger
}

Received: 7 November 2007 / Accepted: 7 April 2008/Published online: 3 June 2008

(C) The Author(s) 2008

\begin{abstract}
The spatial and temporal patterns of resource distribution in a desert system have been shown to influence a number of soil biota components and processes. The pattern of possible different resources supplied by two typical halophyte shrubs with different ecophysiological adaptations, Atriplex halimus and Hammada scoparia, was found to be the trigger in the present study on the microbial community temporal and spatial (vertical) scale. The uniqueness of $A$. halimus, a saltbush plant, is in the creation of 'islands of salinity' in its rhizosphere system and the relatively high percentage of organic matter beneath its canopy, whereas the H. scoparia shrub has a leafless stem with a relatively lower amount of organic matter accumulation beneath its canopy. Soil samples from 0 to $50 \mathrm{~cm}$ depths were collected at $10-\mathrm{cm}$ intervals during each of the four seasons. The vertical distribution of the microbial community was measured in the vicinity of the above plant shrubs and in the open spaces between them. The results obtained from the field study demonstrated that plant ecophysiological adaptation played an important role in the temporal and spatial distribution of abiotic conditions and microbial community levels such as microbial biomass, $\mathrm{CO}_{2}$ evolution, and colony-forming units (CFUs) of both bacteria and fungi. However, we did not find consistency in the positive effect of plant cover on the microbial community. The shrub effect
\end{abstract}

G. Barness · I. Shmueli • Y. Steinberger $(\bowtie)$

The Mina and Everard Goodman Faculty of Life Sciences,

Bar-Ilan University,

Ramat Gan 52900, Israel

e-mail: steinby@mail.biu.ac.il

S. Rodriguez Zaragoza

Lab de Microbiologia, Unidad de Biologia Tecnolodia y Prototipos, Facultad de Estudios Superiores Iztacala, UNAM,

Mexico City, Mexico was observed to have a major outcome on microbial variables not only on a temporal but also on a spatial (vertical) basis. This contributed to the understanding of the controversy regarding the difference between the shrubs.

\section{Introduction}

Microorganisms are not uniformly distributed in the environment. Rather, their abundance, activity, and trophic composition change along environmental gradients [42]. Soil systems are particularly known as being heterogeneous. This heterogeneity occurs as a result of the interaction of a hierarchical series of interrelated abiotic variables that fluctuate at different spatial and temporal scales. The main factors affecting the soil microbial community in desert systems are both biotic (e.g., protozoa, nematodes, microarthropods, etc.) and abiotic (e.g., rainfall, temperature, evaporation, etc.) components [7, 12, 35, 39]. The activity and density of the microbial community living in a desert soil system were found to be dependent on moisture and organic matter availability, and the physical and chemical properties of the soil milieu $[13,46]$. The spatial and temporal patterns of resource distribution in a desert system have been shown to influence a number of soil biotic components and processes [38, 47], whereas climate and topography were found to be the main driving forces creating the spatial and temporal patterns of plant community dynamics [1]. To overcome the sparse, sporadic, and unpredictable moisture input in desert systems [26, 28], plants have developed different ecophysiological adaptations, the most common being excretion of salt on aboveground parts. Plants absorb salts through their root systems, translocating them to the leaves and redepositing them on the soil surface [45], which results in 'islands of 
salinity' under the plant canopies [36]. As a result of this, the plants provide a multitude of microniches, mediating abiotic conditions and supplying organic matter. In addition, accumulating evidence indicates that the plant rhizosphere plays an important role in soil biotic vertical distribution, especially in desert ecosystems [27, 29, 38].

Because of the complexity of the desert system where soil physical-chemical properties, plant ecophysiological adaptation, and temperature-moisture characteristics are closely integrated, the temporal and spatial heterogeneity of nutrient sources will certainly facilitate soil biota coexistence and activity. In such a complex desert system, marked not only by plant niche effect but also by unpredictable 'rainfall pulses' and low nutrient availability, well-integrated microbial population activity is required.

Our aim was to explore the spatial-vertical and temporal variations of the soil microbial community's $\mathrm{CO}_{2}$ evolution, bacterial and fungal population density, and soil abiotic features (e.g., soil moisture, organic matter, and total soluble nitrogen $[\mathrm{TSN}]$ ) on a scale from 0 to $50 \mathrm{~cm}$ at $10-$ $\mathrm{cm}$ intervals under the canopy of Hammada scoparia (Pomen) Iljin and the saltbush Atriplex halimus L., two typical halophyte shrubs in the Negev Desert Highlands. Furthermore, we tested the hypothesis that the spatial variation in the biotic components (e.g., biomass, $\mathrm{CO}_{2}$ evolution, microbial metabolic quotient, and the ratio between bacterial and fungal biomass) will be related to the spatial conditions in the abiotic variables and plant ecophysiological adaptation.

\section{Materials and Methods}

Soil samples were collected from a loessial plain near Sede Boker $\left(34^{\circ} 47^{\prime}\right.$ E, $\left.30^{\circ} 52^{\prime} \mathrm{N}\right)$ in the northern Negev Highlands of Israel. This area has a temperate desert climate with mild, rainy winters $\left(5-14^{\circ} \mathrm{C}\right.$ in January) and hot, dry summers $\left(18-32^{\circ} \mathrm{C}\right.$ in June). Radiation may reach $3.14 \times 104 \mathrm{~kJ} \mathrm{~m}^{-2}$ day $^{-1}$. The average multiannual rainfall is $98 \mathrm{~mm}$; however, rainfall fluctuates between $34 \mathrm{~mm}$ in a drought year to $187 \mathrm{~mm}$ in an extremely rainy year. Rainfall occurs only during the winter months (November-April). An additional source of moisture is dew formation, which contributes a value equal to approximately $35 \mathrm{~mm}$ rainfall. The potential annual evaporation rate is approximately $2,615 \mathrm{~mm}$ [11]. The soils are brown, shallow, rocky desert soil (brown lithosols) and loessial, gray desert soils (loessial sierozems) [9]. The most characteristic plants at the site are H. scoparia, Artemisia herba-alba, and A. halimus L. with similar rooting systems $[10,11]$.

Within an area of approximately $50 \times 50 \mathrm{~m}$, we randomly selected 20 plants of each species for sampling. With the use of a corer, four replicate soil samples were collected at random from under the canopies of $H$. scoparia $(60 \mathrm{~cm}$ wide and about $50-70 \mathrm{~cm}$ high) and A. halimus $(70 \mathrm{~cm}$ wide and $80-120 \mathrm{~cm}$ high), which grow in the same system and differ in their ecophysiological adaptation [11], and also from open spaces between the shrubs (control). The soil samples were collected during each of the four seasons: winter (January), spring (April), summer (July), and autumn (September), in 2001. Samples were collected from 0 to $50 \mathrm{~cm}$ depth, at $10-\mathrm{cm}$ increments (corresponding to 0 $10,10-20,20-30,30-40$, and $40-50 \mathrm{~cm}$ depths) at each site. Samples from each layer of each replicate were placed in individual plastic bags and transported to the laboratory in an insulated container to avoid excessive heat during hot weather. Before processing, soil samples were sieved (2$\mathrm{mm}$ mesh size) to remove root segments and other organic debris. Subsamples corresponding to $0-10,10-20,20-30$, $30-40$, and $40-50 \mathrm{~cm}$ depths were collected from each sample. Subsamples from each replicate of each $10-\mathrm{cm}$ increment were used to determine soil moisture, organic matter, and TSN, as per the following:

1. Soil water content was determined gravimetrically by drying a 3-g subsample at $105^{\circ} \mathrm{C}$ for $48 \mathrm{~h}$.

2. Soil organic carbon content was calculated from the percentage of organic carbon estimated by oxidization with dichromate in the presence of $\mathrm{H}_{2} \mathrm{SO}_{4}[31,48]$.

3. TSN. A subsample of $10.0 \mathrm{~g}$ was extracted from each sample with $25 \mathrm{~mL} 0.01 \mathrm{~N} \mathrm{CaCl}_{2}$ solution by shaking for $90 \mathrm{~min}$ [16]. The amounts of TSN in the soil extract were determined using a Skalar Autoanalyzer System [32].

4. Colony-forming units (CFUs) of bacterial and fungal culturable density were determined in $1 \mathrm{~g}$ soil samples from each of the samples $(n=4)$ collected during the sampling period using serial dilutions $10^{-5}$ and $10^{-2}$ for bacteria and fungi, respectively, according to Kinsbursky et al. [21].

5. Soil microbial biomass $(\mathrm{MB})$ and $\mathrm{CO}_{2}$ respiration were evaluated by substrate-induced respiration (SIR) at $40 \%$ water holding capacity, using an infrared gas analyzer (IRGA) $[2,15,19]$. Atmospheric $\mathrm{CO}_{2}$ levels were used as a baseline. The IRGA unit is a 24-channel computerized system that enables $\mathrm{CO}_{2}$ readings and continuously determines both microbial activity and MB. These two results enable the calculation of the competitive efficiency of the soil microbial population under environmental conditions.

The coefficient $\left(\mathrm{qCO}_{2}\right)$ was calculated as follows:

$\mathrm{qCO}_{2}=\frac{\mathrm{CO}_{2} \text { production }}{\text { biomass }} \times 10^{3}$.

This metabolic index for $\mathrm{CO}_{2}$ is a specific parameter for evaluating the effects of environmental conditions on soil MB [5]. 
The microbial coefficient, known as the ratio between MB carbon to total organic carbon $\left(C_{\mathrm{mic}} / C_{\mathrm{org}}\right)$, was determined to evaluate substrate availability $[17,18]$.

Statistical analysis was performed by SAS (GLM, Duncan's multiple range test, coefficient of correlation), whereas EXCEL analysis [40] was used to examine the differences in vegetation, soil microbial community, and vertical distribution.

Percentages of soil moisture and organic matter were normalized by arc sin transformation $[b=(2 / \pi) \arcsin (\sqrt{ } X i j)$ [41]] before canonical correspondence analysis (CCA). This ordination was performed to explore the correlation between microbial parameters and the physical conditions of the soils. A Monte Carlo test was set up to 999 runs to determine the significance of the ordination. Bray Curtis analysis was performed to analyze seasonal patterns at the 0 - to $50-\mathrm{cm}$ soil profile. Both analyses were performed using PC Ord@ software version 4 for Windows $([6,24$, 25]. Ordination by soil layer was achieved by reciprocal averaging (RA) using the PC Ord $\odot$ version 4 for Windows $\mathbb{C}$.

\section{Results}

\section{Soil Moisture}

Soil moisture in the samples collected under A. halimus and H. scoparia and from control plant interspaces was found to show similar trends throughout the year with a significantly $(p<0.05)$ higher moisture level of $6.9 \%, 6.8 \%$, and $8.9 \%$, respectively, in the 0 - to $10-\mathrm{cm}$ depth during the winter rainy season in comparison to the deeper layers (Fig. 1). However, a significant $(p<0.001)$ difference was observed between the control soil (8.9\%) and the two shrubs, $A$. halimus and H. scoparia at the $0-$ to 10 -cm layer $(6.8 \%$ and $6.9 \%$, respectively) during the study period. Moreover, the lowest soil moisture levels were found at the upper 0- to 10$\mathrm{cm}$ soil layers in the summer season with a percentage of $1.9,1.4$, and 1.9 in the vicinity of $A$. halimus, $H$. scoparia, and the control samples, respectively. No significant differences at the level of $p<0.05$ were obtained between the two plants and control samples during the study period. Furthermore, soil moisture content levels in the upper (0$10 \mathrm{~cm})$ and deepest $(40-50 \mathrm{~cm})$ layers were found to be greater $(p<0.05 ; d f=180)$ than in the other three layers.

\section{Soil Organic Carbon}

Soil organic carbon levels showed a different pattern compared to soil moisture. In the two upper soil layers $(0-10$ and $10-20 \mathrm{~cm})$ (Fig. 1), organic carbon levels were found to be significantly $(p<0.001)$ higher in comparison to the control interspace soil samples, whereas in the deeper soil layers, no significant differences at the level of $p<0.05$ were observed. The highest values $(0.95 \%)$ in organic carbon were found in the vicinity of A. halimus in the 0 - to $10-\mathrm{cm}$ upper layer in autumn. At the same layer, a significantly $(p<0.01)$ lower mean value $(0.53 \%)$ was observed in spring (Fig. 1). Soil organic carbon was found to decrease significantly $(p<0.05)$ toward the deeper layer to mean values ranging between $0.21 \%$ and $0.38 \%$. In the vicinity of $H$. scoparia, soil organic carbon was found to range between $0.75 \%$ and $0.58 \%$ in the upper $(0-10 \mathrm{~cm})$ soil layers with a gradual decrease toward the deeper layer to mean twofold lower values ranging between $0.23 \%$ and $0.31 \%$ for autumn and winter, respectively. This was mainly the result of plant leaf-shedding and annual plantpart accumulation. In the intershrub control samples, the mean soil organic values were found to range between $0.49 \%$ and $0.15 \%$, showing a significant threefold decrease in its vertical distribution during winter (Fig. 1).

\section{Soil Total Soluble N}

Mean TSN distribution in the soil collected during the study period was found to range between 8.4 and 1.6, 22.4 and 2.6, and 7.9 and $1.7 \mathrm{ppm}$ for A. halimus, H. scoparia, and control samples, respectively. The TSN under $A$. halimus was found to be significantly higher $(p<0.001)$ in the 0 - to $10-\mathrm{cm}$ soil layer during the whole sampling period (Fig. 2), whereas in the deeper layers, such as 10-20, 2030 , and $30-40 \mathrm{~cm}$, the TSN under $A$. halimus was found to be significantly higher $(p<0.05)$ in the spring, summer, and autumn seasons. At the deepest $(40-50 \mathrm{~cm})$ layer, $H$. scoparia showed higher TSN values only in the summer period. No significant differences in TSN between the soil samples collected in the vicinity of $A$. halimus and control were found in the soil layers between 10 and $50 \mathrm{~cm}$ (Fig. 2). The only significant $(p<0.05)$ difference between the $A$. halimus and control soil samples was obtained in the upper $(0-10 \mathrm{~cm})$ layer in the spring, summer, and autumn sampling periods, whereas in the winter season, the TNS in the control samples was found to be almost threefold lower.

\section{Bacterial and Fungal CFUs}

The results obtained for bacterial and fungal CFUs are presented in Fig. 3 where, in general, a complementary picture between the two (affected by sampling location) can be seen. The bacterial density in all the samples was found to be significantly $(p<0.001)$ higher in summer and autumn in all the soil layers in the vicinity of $H$. scoparia and the control intershrub soil samples with values ranging between $46-107 \times 10^{5}$ and $65.5-87.5 \times 10^{5}$ CFU g ${ }^{-1}$ dry soil, 
Figure 1 Seasonal variation in the vertical distribution of percentages of soil moisture content and soil organic carbon in the vicinity of $A$. halimus, H. scoparia, and control (open space) sampling sites
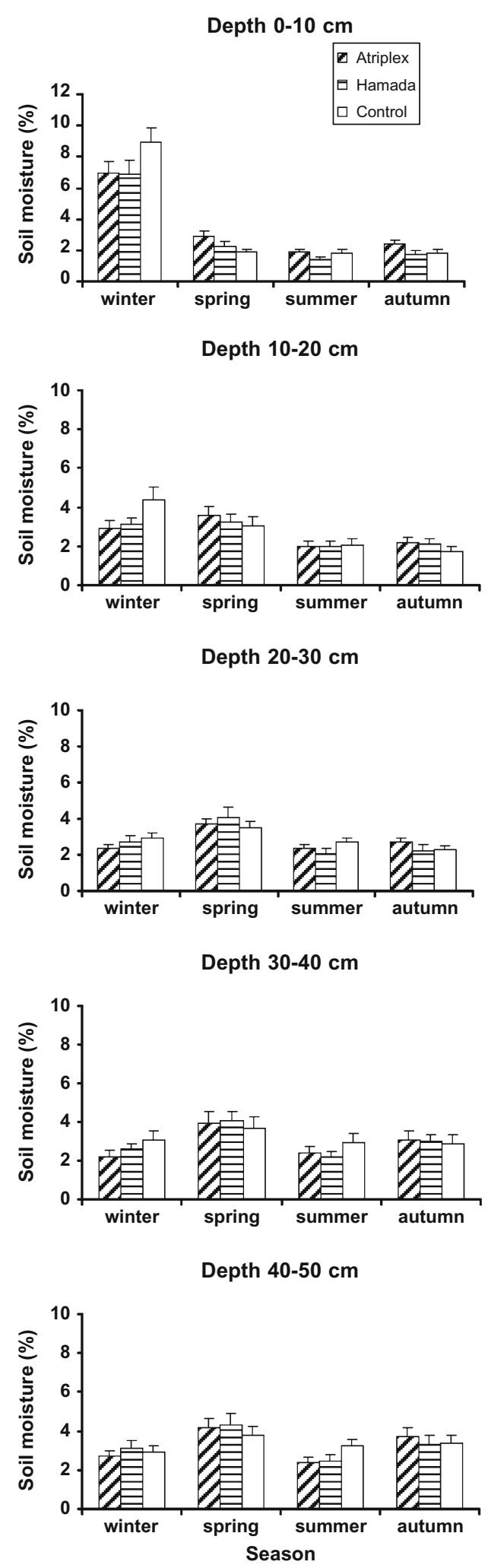

Depth 0-10 cm

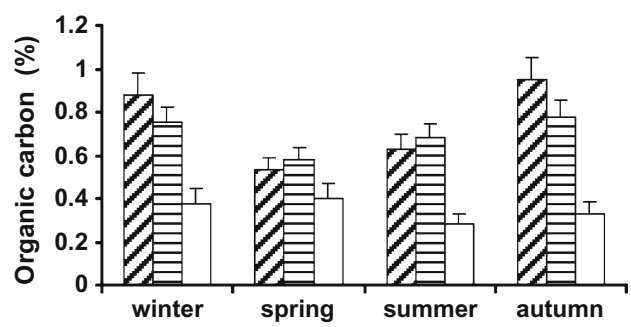

Depth $10-20 \mathrm{~cm}$
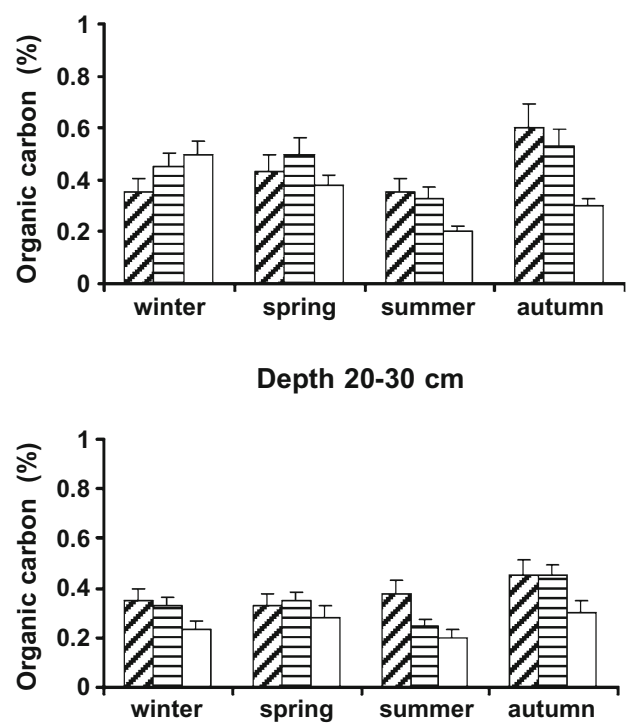

Depth $30-40 \mathrm{~cm}$
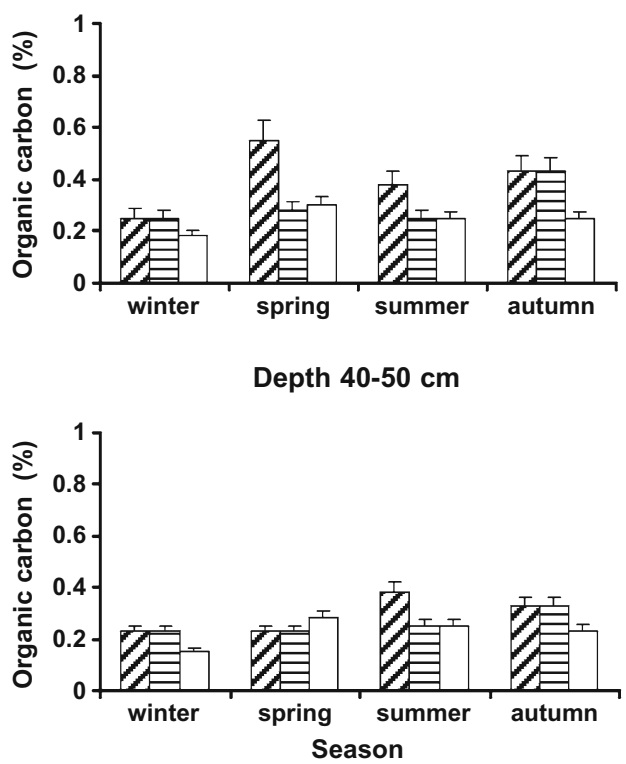

respectively. In the winter and spring seasons, the microbial density at the above sampling sites ranged between 9$32.3 \times 10^{5}$ and $17-37.3 \times 10^{5} \mathrm{CFU} \mathrm{g}^{-1}$ dry soil, respectively. The microbial density level in the soil samples collected in the vicinity of $A$. halimus was found to be significantly ( $p<$ 0.05 ) higher in autumn at all the soil layers in comparison to the other seasons with values increasing from the upper $(0-10 \mathrm{~cm})$ layer $\left(32.8 \times 10^{5} \mathrm{CFU} \mathrm{g}^{-1}\right.$ dry soil $)$ to the deeper 
Depth $0-10 \mathrm{~cm}$
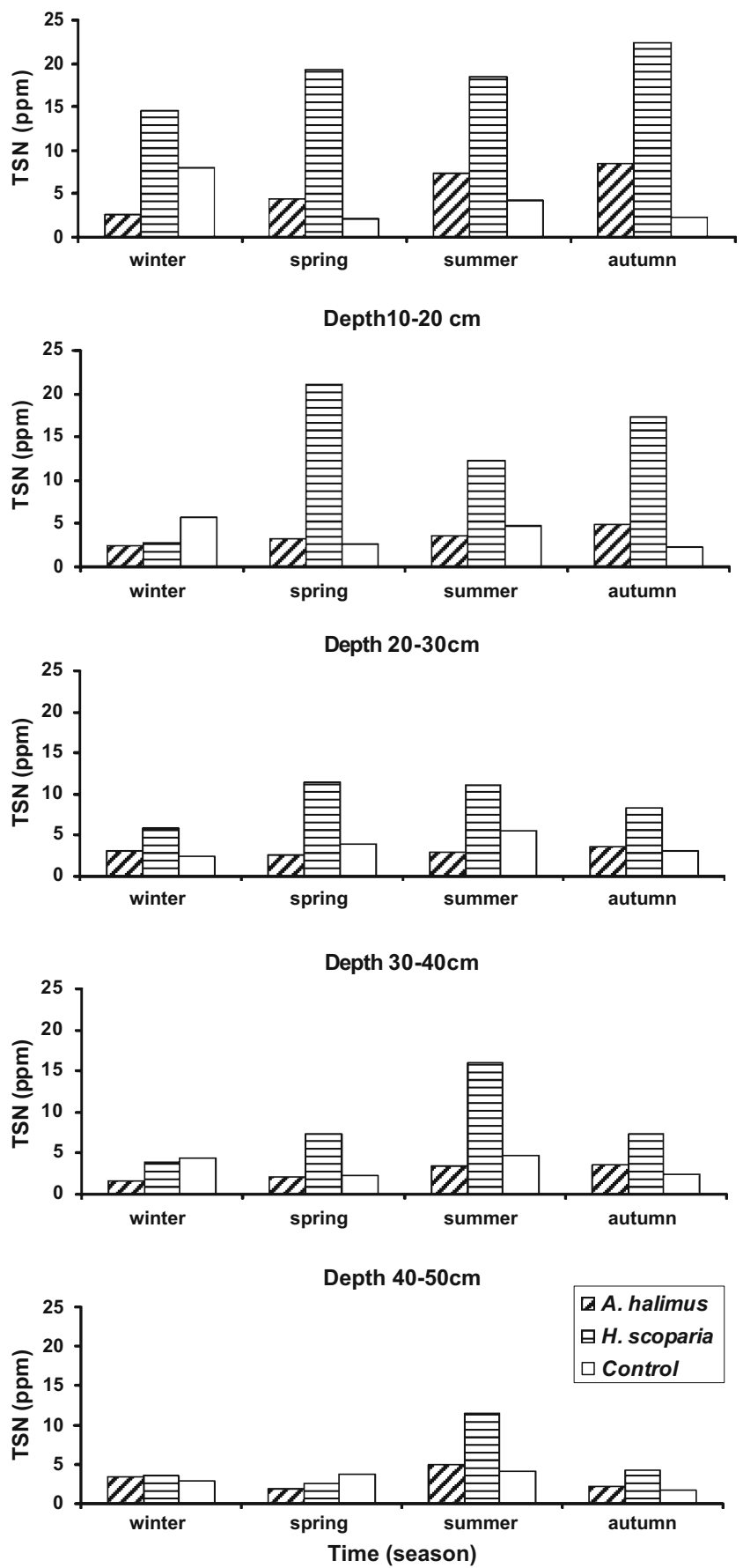

Figure 2 Seasonal variation in soil TSN at the different soil layers from the 0 - to $50-\mathrm{cm}$ depth in samples collected in the vicinity of $A$. halimus, H. scoparia, and control sites throughout the study period

$(40-50 \mathrm{~cm})$ layer $\left(54.3 \times 10^{5} \mathrm{CFU} \mathrm{g}^{-1}\right.$ dry soil), whereas in the winter season, the values dropped to a minimum of $3.8 \times 10^{5} \mathrm{CFU} \mathrm{g}^{-1}$ dry soil (Fig. 3).

The highest fungal density was obtained in winter with maximum values of $36.8,72.8$, and $54.8 \times 10^{2} \mathrm{CFU} \mathrm{g}^{-1}$ dry soil in the 10-20 cm layers for A. halimus, H. scoparia, and control sampling locations, respectively. In contrast, the lowest values were observed in autumn for A. halimus and in spring for $H$. scoparia and control samples with values of $0.75,0.25$, and $0.5 \times 10^{2} \mathrm{CFU} \mathrm{g}^{-1}$ dry soil, respectively (Fig. 3).

\section{Microbial Biomass and $\mathrm{CO}_{2}$ Evolution}

Soil MB showed similar trends in all the soil layers. MB in soil samples collected in the vicinity of $H$. scoparia was almost steady with values ranging between 108 and $128 \mu \mathrm{g} \mathrm{C} \mathrm{g}^{-1}$ dry soil (Fig. 4), whereas MB in soil samples collected in the vicinity of $A$. halimus was found to be significantly $(p<0.01)$ higher in comparison to H. scoparia. Moreover, a continuous decline in $\mathrm{MB}$ from winter to autumn along the vertical profile from a maximal value of $196 \mu \mathrm{g} \mathrm{C} \mathrm{g}^{-1}$ dry soil to a minimum value of $159 \mu \mathrm{g} \mathrm{C} \mathrm{g}^{-1}$ dry soil was observed. In addition, the range between the maximal $\mathrm{MB}$ value in winter to the minimal value in autumn under $A$. halimus showed a continuous decrease from the upper $(0-10 \mathrm{~cm})$ soil layer to the deeper $(40$ $50 \mathrm{~cm}$ ) soil layer with values such as $38,32,28,10$, and $2 \mu \mathrm{g} \mathrm{g} \mathrm{g}^{-1}$ dry soil (Fig. 4).

Soil $\mathrm{CO}_{2}$ evolution in the control samples along the sampling profile was found to fluctuate slightly between 2.2 and $1.4 \mu \mathrm{g} \mathrm{CO}_{2}-\mathrm{C}(\mathrm{g} \text { soil } \mathrm{h})^{-1}$ with a relatively high value in winter, which decreased toward the autumn season. In soil samples collected in the vicinity of $H$. scoparia, an opposite trend was found, exhibiting significant $(p<0.05)$ differences between winter and autumn with a steady increase along the soil profile from low values in winter and high values in autumn ranging from mean values of 1.9 to $5.2 \mu \mathrm{g} \mathrm{CO}_{2}-\mathrm{C}$ (g soil h) ${ }^{-1}$ (Fig. 4).

Metabolic Quotient Index $\left(\mathrm{qCO}_{2}\right)$ and Microbial Coefficient $\left(C_{\text {mic }} / C_{\text {org }}\right)$

The $\mathrm{qCO}_{2}$ was found to be similar with no vertical effect between the three sampling locations in the spring season, whereas a divergent trend was observed before and after this season (Fig. 5). A similarity between all treatments at all depths throughout the seasons can be exhibited in three different trends: (1) a continuous and significant $(p<0.01)$ increase in $\mathrm{qCO}_{2}$ values (ranging between 18.7 and $\left.42.0 \mathrm{mg} \mathrm{CO}{ }_{2}-\mathrm{C}\left(\mathrm{gC}_{\text {mic }} \times \mathrm{h}\right)^{-1}\right)$ in the samples collected in the vicinity of $H$. scoparia; (2) a continuous significant ( $p<$ $0.01)$ decrease in $\mathrm{qCO}_{2}$ levels in samples collected in the control intershrub samples, from a maximal value of 48.8 to a minimal value of $11.2 \mathrm{mg} \mathrm{CO}-\mathrm{C}\left(\mathrm{g} C_{\text {mic }} \times \mathrm{h}\right)^{-1}$; and (3) the $\mathrm{qCO}_{2}$ pattern obtained for $A$. halimus showing a similar trend with a significantly $(p<0.05)$ lower value at $10-20$, 20-30, and $30-40 \mathrm{~cm}$ soil layers between winter and autumn seasons (Fig. 5). 

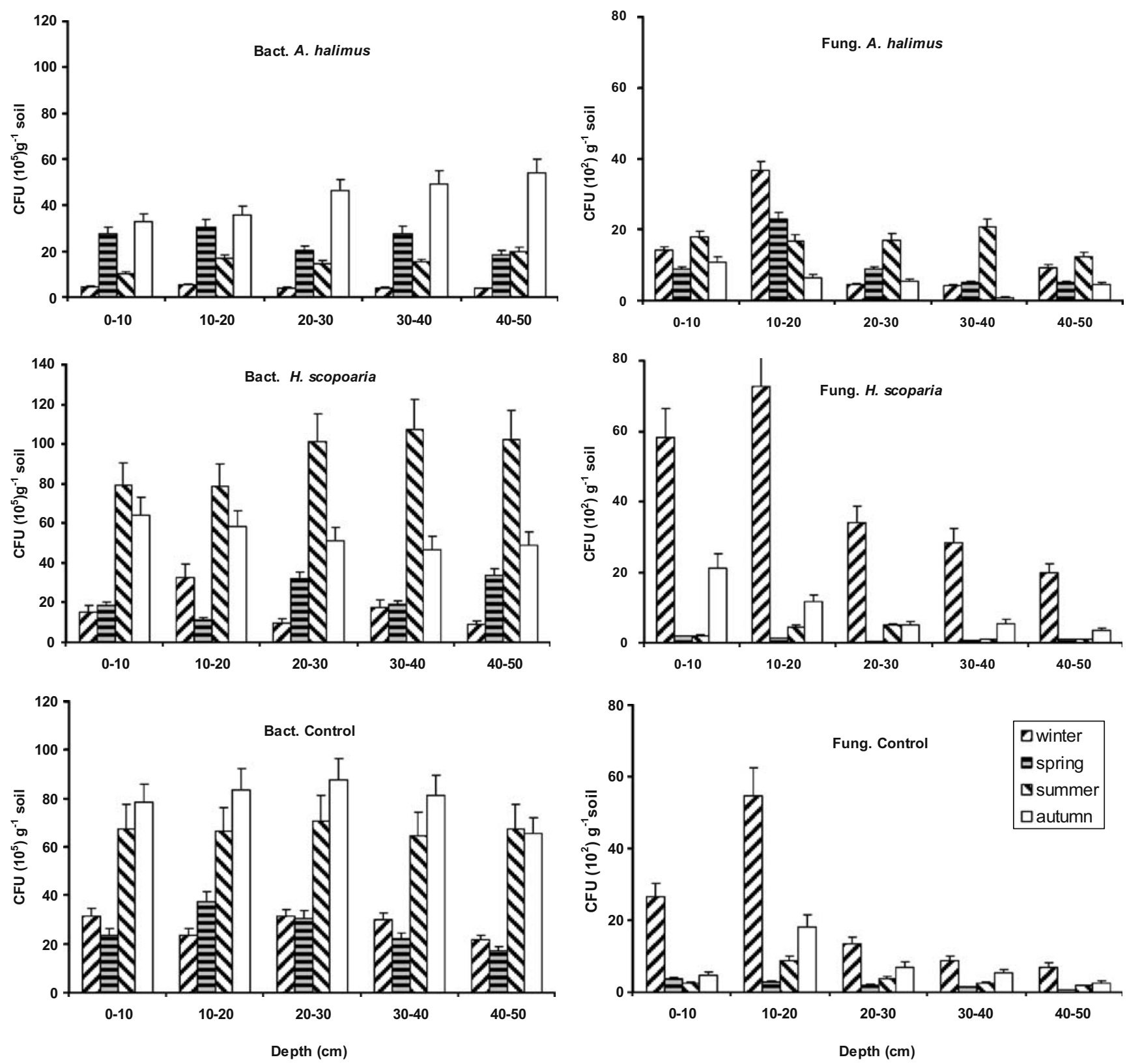

Figure 3 Seasonal effect on the vertical distribution of CFUs of bacterial and fungal populations in soil samples collected in the vicinity of $A$. halimus, $H$. scoparia, and control sites throughout the study period

The $C_{\text {mic }} / C_{\text {org }}$ ratio consistently reflected the seasonal and plant effect with a significant $(p<0.05)$ difference between the three sampling sites where A. halimus $>H$. scoparia $>$ control samples at the 10 - to 50 -cm soil layers for the winter season only (Fig. 5). In the $0-$ to $10-\mathrm{cm}$ soil layer, no significant $(p>0.05)$ differences were observed between the three sampling locations for the winter and spring seasons. Moreover, no significant differences between the soil samples collected in the vicinity of the two shrubs were obtained for summer and autumn, whereas in the control soil samples, a significant increase $(p<0.001)$ in the $C_{\text {mic }} / C_{\text {org }}$ ratio was obtained toward the summer season for the $0-10,10-20$, and $20-30 \mathrm{~cm}$ soil layers, followed by a sharp $(p<0.01)$ decrease toward autumn (Fig. 5).

No significant correlation was found between MB, organic carbon, and TSN in soil samples collected in the vicinity of $A$. halimus (Fig. 6). The MB in the soil samples collected in the vicinity of $H$. scoparia throughout the study period showed a positive and significant $(r=0.71)$ correlation with the $C_{\text {org }}$ levels where, similar to A. halimus, no correlation between the MB and TSN was obtained (Fig. 6). However, in control soil samples collected throughout the study period, the MB showed a negative slope with $C_{\text {org }}$ and TSN at $r=0.67$ and $r=0.14$, respectively (Fig. 6). 
Depth 0-10 cm

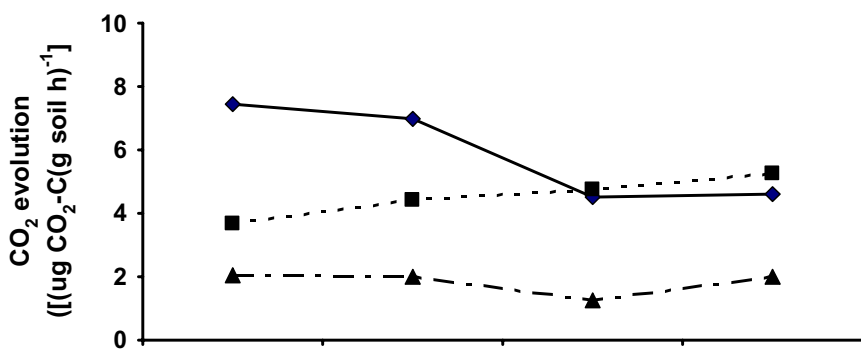

Depth $10-20 \mathrm{~cm}$

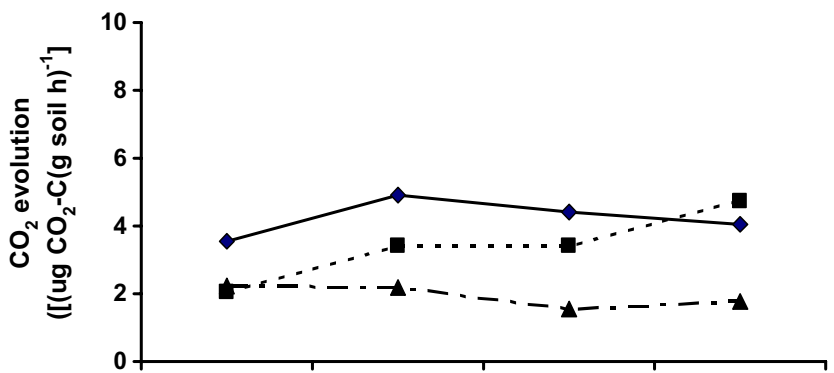

Depth 20-30 cm

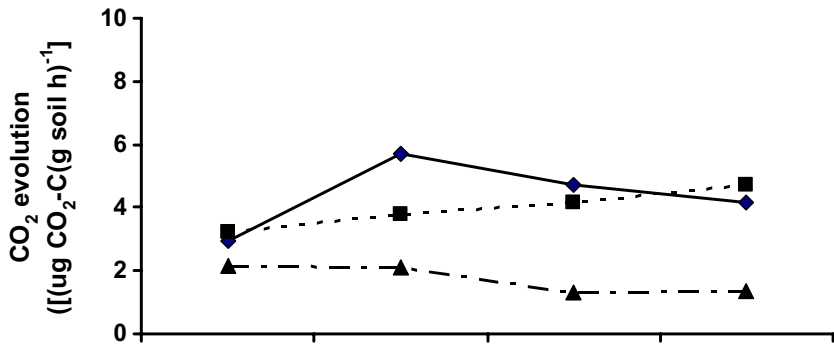

Depth $30-40 \mathrm{~cm}$

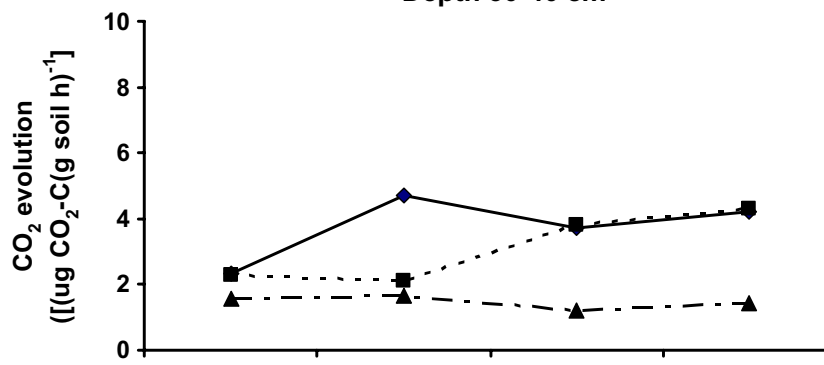

Depth $40-50 \mathrm{~cm}$

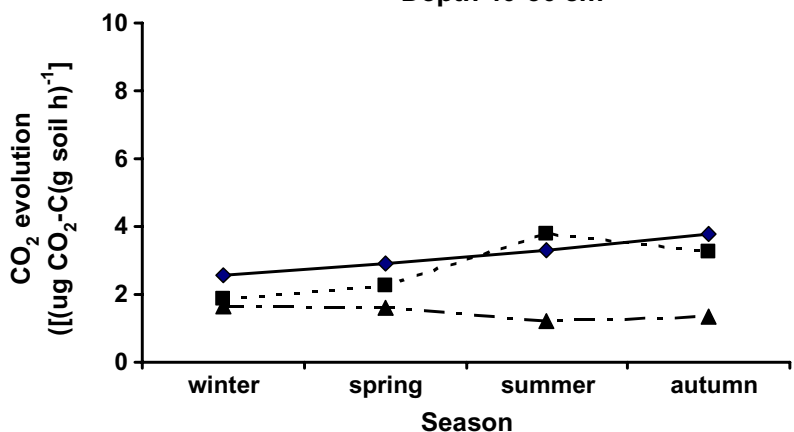

Depth 0-10 cm

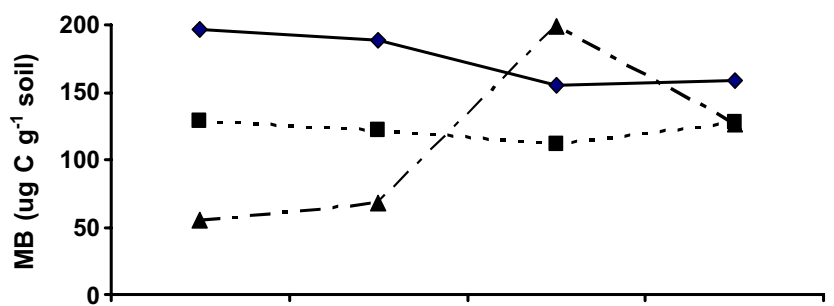

Depth 10-20 cm

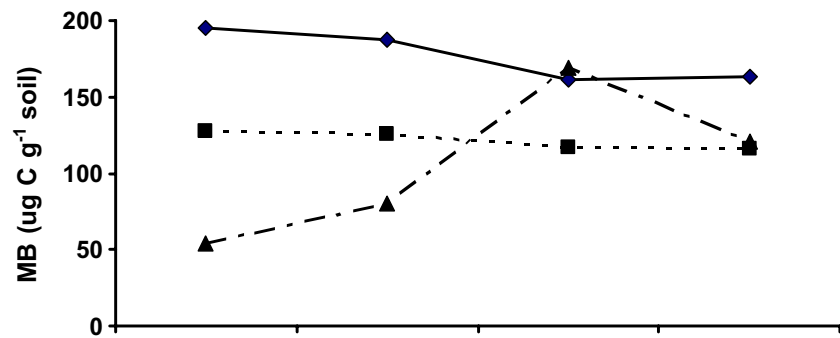

Depth $20-30 \mathrm{~cm}$
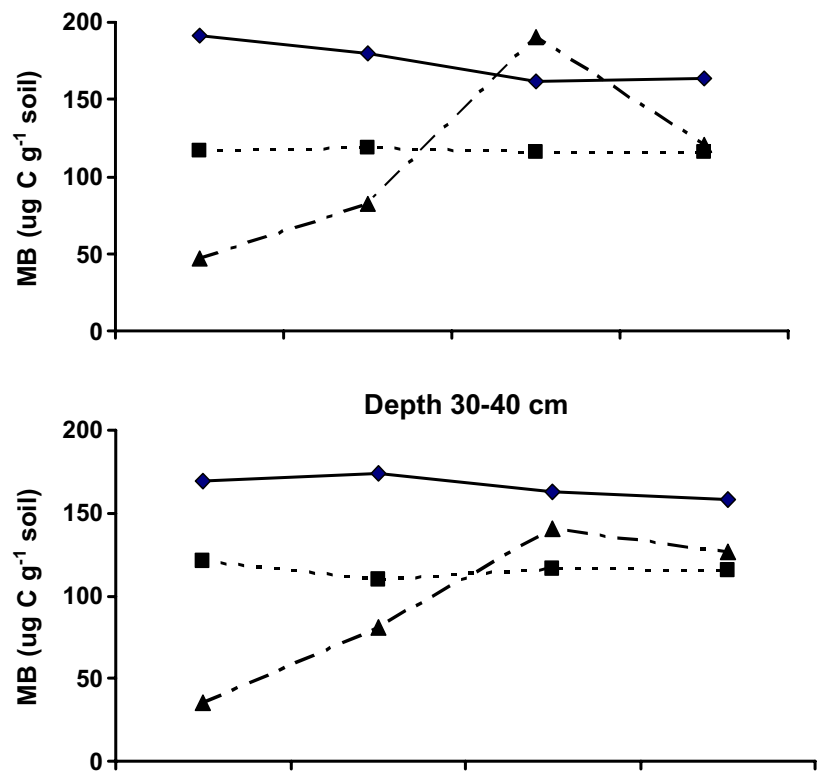

Depth 40-50 cm

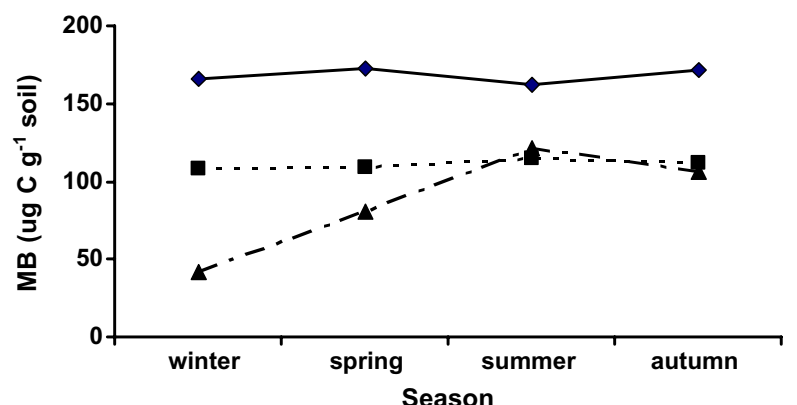

Figure 4 Seasonal and vertical variation in total $\mathrm{MB}$ and $\mathrm{CO}_{2}$ evolution during the study period in the vicinity of $A$. halimus (filled diamonds), $H$. scoparia (filled squares), and control (filled triangles) sampling sites 

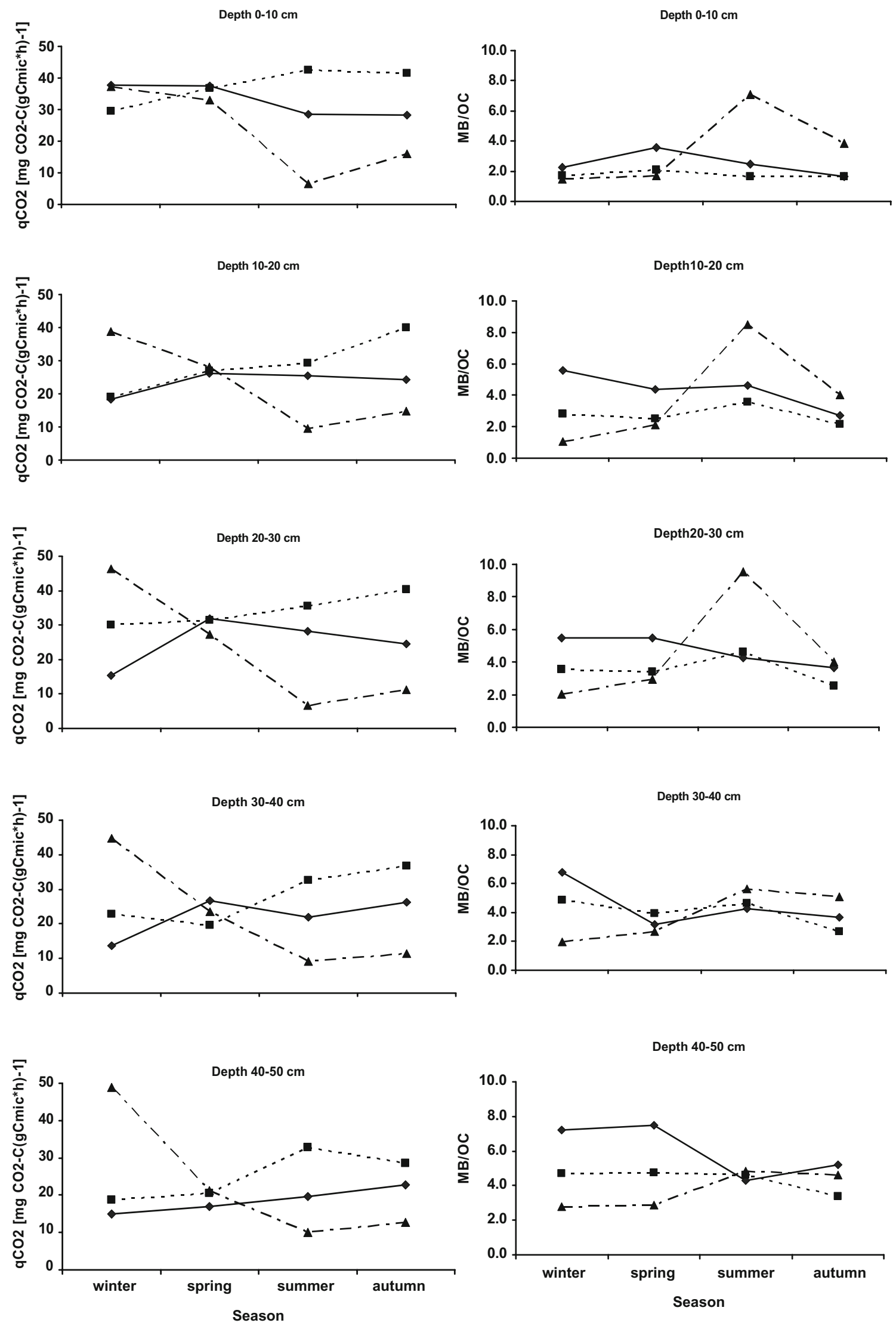

Figure 5 Seasonal variation in the metabolic quotient index $\left(\mathrm{qCO}_{2}\right)$ and microbial coefficient $\left(C_{\text {mic }} / C_{\text {org }}\right)$ during the study period in soil samples collected in the vicinity of A. halimus (filled diamonds), H. scoparia (filled squares), and control (filled triangles) sites 
Figure 6 Correlations among $\mathrm{MB}$, organic carbon, and TSN in soil samples collected throughout the study period in the vicinity of $A$. halimus, $H$. scoparia, and control sites
A. halimus

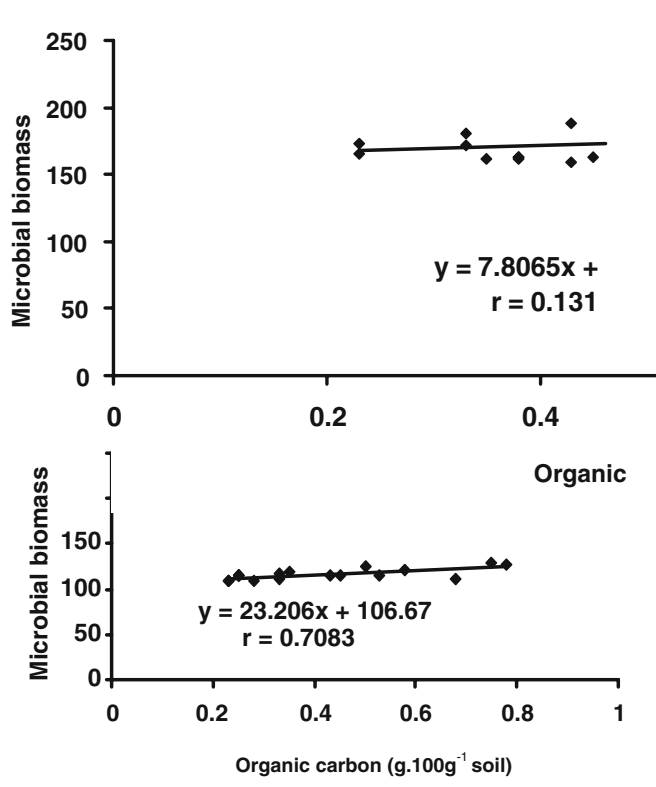

Control

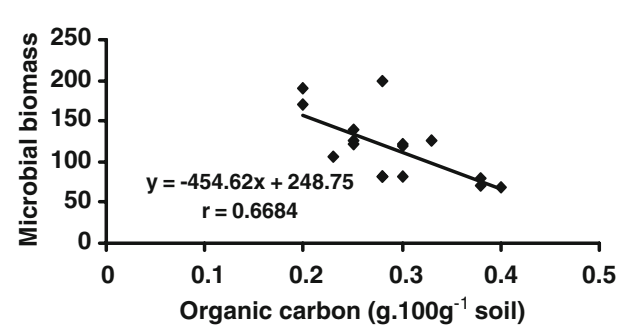

A. halimus

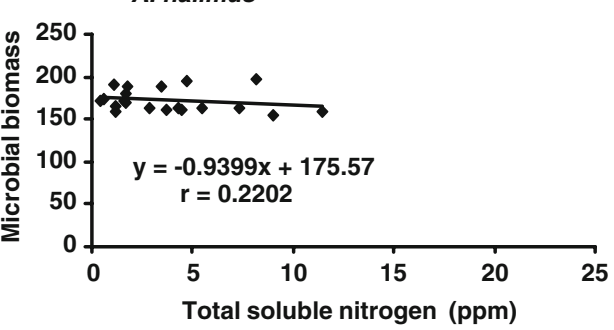

H.scoparia

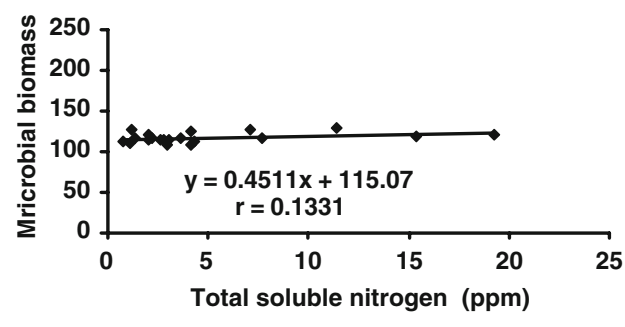

Control

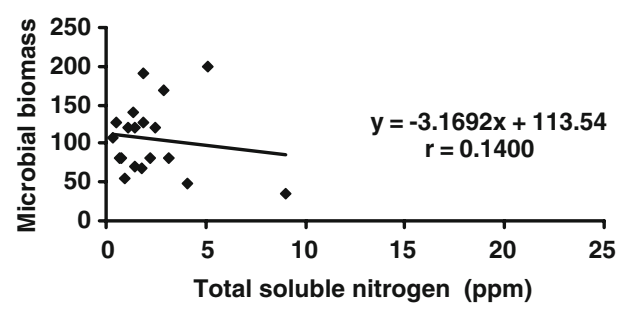

Canonical Correspondence Analysis

CCA of microbial characteristics and physical conditions of soil under A. halimus and H. scoparia in the Negev Desert showed that the two main axes of ordination explained $48.8 \%$ of the variance: the first axis (soil moisture) explained 37\%; the second axis (organic matter) explained $11.8 \%$. The Monte Carlo test for randomization reached a value of $p=0.03$ after 998 runs for both eigenvalues and species-environment correlations.

Ordination of microbial functions under bushes showed that $\mathrm{MB}$, fungal counts, and bacterial counts were associated with soil moisture and organic matter, whereas respiration and $\mathrm{CO}_{2}$ quotient under bushes and control soil were more independent of these factors (Fig. 7).

At the 10-cm depth, soil moisture was the leading factor for most of the biological functions in soil, especially during winter and spring. MB, fugal counts, and bacterial counts were more closely correlated with these two environmental factors (except the fungal counts under $H$. scoparia), whereas the respiration quotient and respiration were uncorrelated to these factors (Fig. 8).
Bacterial counts, fungal counts, $\mathrm{MB}$, respiration quotient, and respiration correlated with both the soil moisture and organic matter axes (Fig. 3). However, the $\mathrm{CO}_{2}$ quotient and $\mathrm{CO}_{2}$ from $H$. scoparia and control were uncorrelated to these two factors. Again, the correlation is during winter and spring, whereas summer and autumn are placed outside the correlation vectors (Fig. 9).

The vector of organic matter under A. halimus followed the opposite direction than that under $H$. scoparia and the control soil during winter, spring, summer, and autumn. In this way, all the biological functions under $A$. halimus correlate with both environmental factors throughout the seasons, except respiration quotient and respiration. Soil under $H$. scoparia and control soil showed similar variation in soil moisture and organic matter, these two factors being very important for bacterial and fungal counts under $H$. scoparia. In control soil, respiration quotient, respiration, and MB remained uncorrelated to these factors (Fig. 10).

At the $40-\mathrm{cm}$ depth, the ordination of biological functions with soil moisture and organic matter was only noticeable under $A$. halimus and control soil, whereas this correlation was noticeable under $H$. scoparia only during 


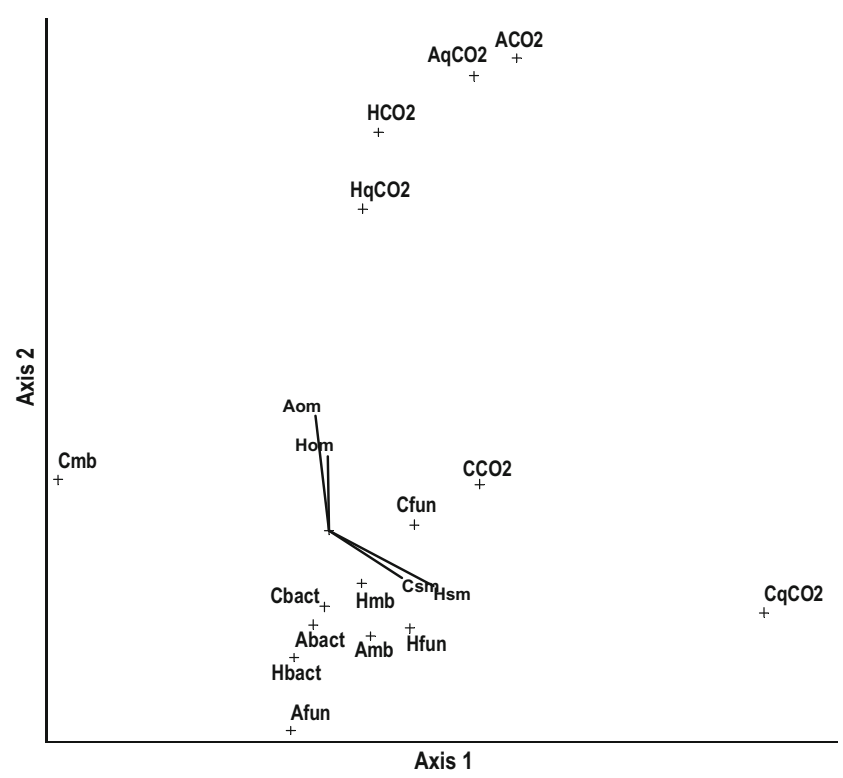

Figure $7 \mathrm{CCA}$ ordination of the microbial and environmental variables in the 0-50 soil profile under $A$. halimus, $H$. scoparia, and control soil. Amb A. halimus microbial biomass, Hmb H. scoparia microbial biomass, $\mathrm{Cmb}$ control soil microbial biomass, $\mathrm{ACO}_{2}$ respiration under $A$. halimus, $\mathrm{HCO}_{2}$ respiration under $\mathrm{H}$. scoparia, $\mathrm{CCO}_{2}$ respiration under control soil, $A q C \mathrm{O}_{2}$ quotient of $\mathrm{CO}_{2}$ under $A$. halimus, $\mathrm{HqCO}_{2}$ quotient of $\mathrm{CO}_{2}$ under $\mathrm{H}$. scoparia, $\mathrm{CqCO}_{2}$ quotient of $\mathrm{CO}_{2}$ under soil control, Abac bacterial counts under $A$ halimus, Hbac bacterial counts under H. scoparia, Cbac bacterial counts under control soil, Afun fungal counts under A. halimus, Hfun fungal counts under H. scoparia, Cfun fungal counts under control soil

the spring. In all the cases, respiration quotient and respiration were uncorrelated to these vectors (Fig. 11).

Microbial activities in the $50-\mathrm{cm}$ depth were uncorrelated to soil organic matter in all seasons, except for the respiration quotient and respiration under $A$. halimus. This influence was present in spring, summer, and autumn. Changes at this soil layer were unrelated to soil moisture (Fig. 12).

\section{Discussion}

Our assumption that plant ecophysiological adaptation plays an important role in the temporal and spatial distribution of abiotic conditions and microbial community levels has been validated, but no consistency was found concerning the positive effect of plant cover. The abiotic variables (e.g., soil moisture, organic matter, etc.) that fluctuated throughout the study period allowed us to identify different environmental niches affected by shrub ecophysiology: (1) litter accumulation ability supplied by A. halimus, also known as the "salt bush" [51, 52]; (2) low organic matter accumulation creating a harsher environment in the vicinity of $H$. scoparia, although creating a better niche for annual plants, even for a shorter period [34]; and

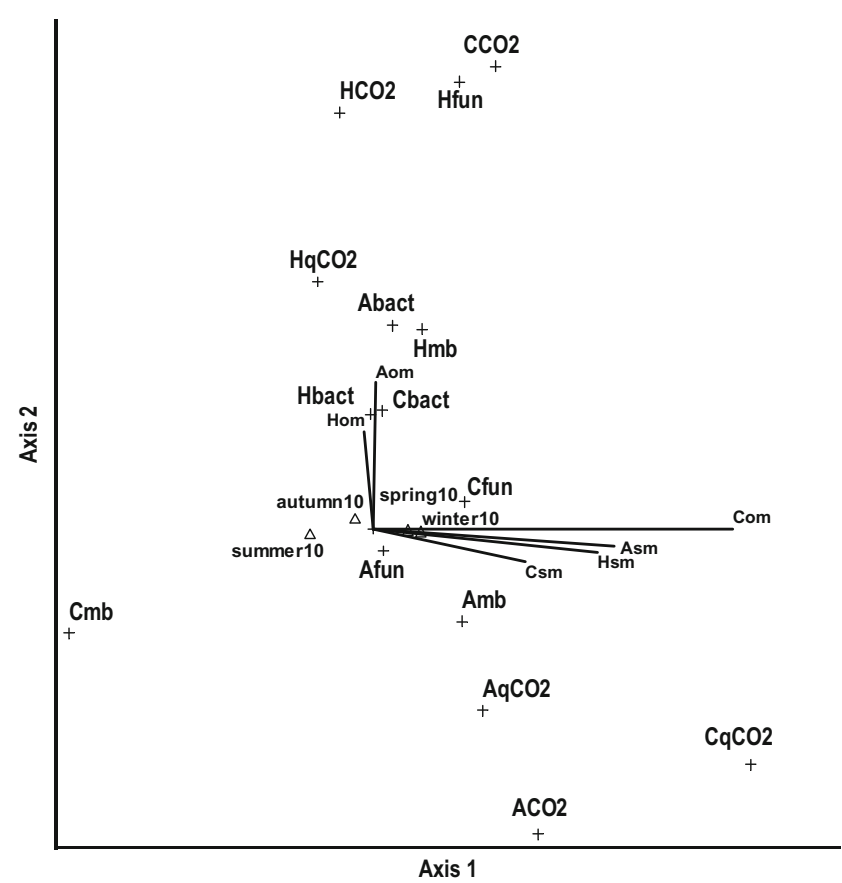

Figure 8 Reciprocal averaging analysis of microbial parameters in the control soil throughout the seasons at the $10-\mathrm{cm}$ depth. Each triangle represents a season (winter, spring, summer, and autumn); crosses represent microbial parameters $-\mathrm{mb}$ microbial biomass, $\mathrm{CO}_{2}$ carbon dioxide, $q \mathrm{CO}_{2}$ quotient of $\mathrm{CO}_{2}$, fun fungal counts, bact bacterial counts. The capital letter before the parameter is the "treatment"-A A. halimus, H H. scoparia, $C$ control soil

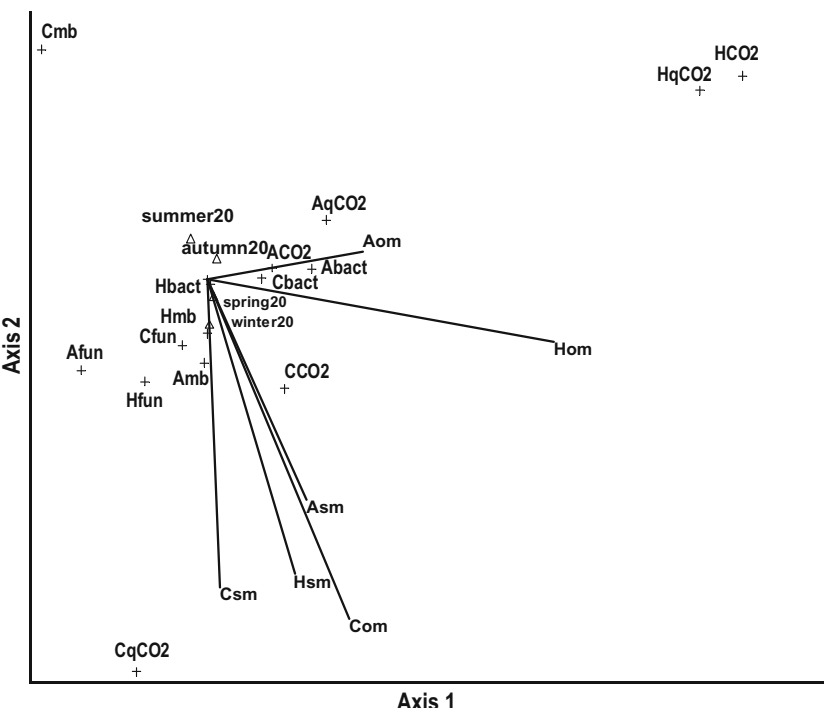

Figure 9 Reciprocal averaging analysis of microbial parameters in the control soil throughout the seasons at the $20-\mathrm{cm}$ depth. Each triangle represents a season (winter, spring, summer, and autumn); crosses represent microbial parameters $-m b$ microbial biomass, $\mathrm{CO}_{2}$ carbon dioxide; $q \mathrm{CO}_{2}$ quotient of $\mathrm{CO}_{2}$, fun fungal counts, bact bacterial counts. The capital letter before the parameter is the "treatment"-A A. halimus, H H. scoparia, C control soil 


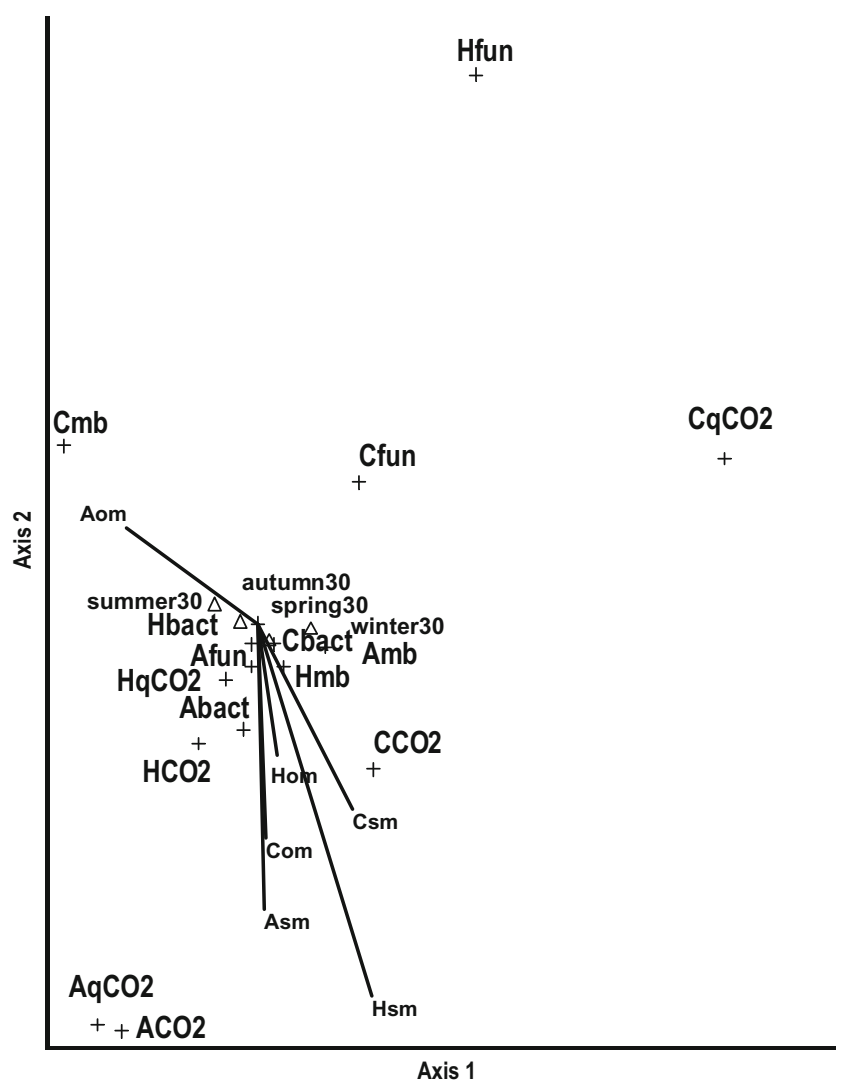

Figure 10 Reciprocal averaging analysis of microbial parameters in the control soil throughout the seasons at the $30-\mathrm{cm}$ depth. Each triangle represents a season (winter, spring, summer, and autumn); crosses represent microbial parameters - $m b$ microbial biomass, $\mathrm{CO}_{2}$ carbon dioxide, $q \mathrm{CO}_{2}$ quotient of $\mathrm{CO}_{2}$, fun fungal counts, bact bacterial counts. The capital letter before the parameter is the "treatment"- $A$ A. halimus, $H$ H. scoparia, $C$ control soil

(3) the well-defined niche-open space, bare soil—where the soil abiotic variables are controlled by environmental conditions. As a result of the above, each one of the three niches responds differently in time and space (vertical), triggered by shrub ecophysiological adaptation combined with environmental factors.

Frostegard and Baath [14] and Saetre and Baath [33], in their study on forest and grassland soils (which differ in organic matter levels), showed that spatial distribution of the microbial community in the soil is related to ground vegetation and soil moisture and, to a large extent, is connected to the quality of soil organic matter associated with the plants. Their results may open new avenues in addition to our findings in a xeric environment, elucidating the importance of ecophysiological divergences in plant adaptation to cope in such a system.

Clark [8], Krasilnikov [22], Wardle [44], and Whitford [46] argued about the extent of the significance of plant rhizosphere on microbial quantity, emphasizing the magnitude of the abovementioned community. However, our data obtained for a xeric environment showed a significant

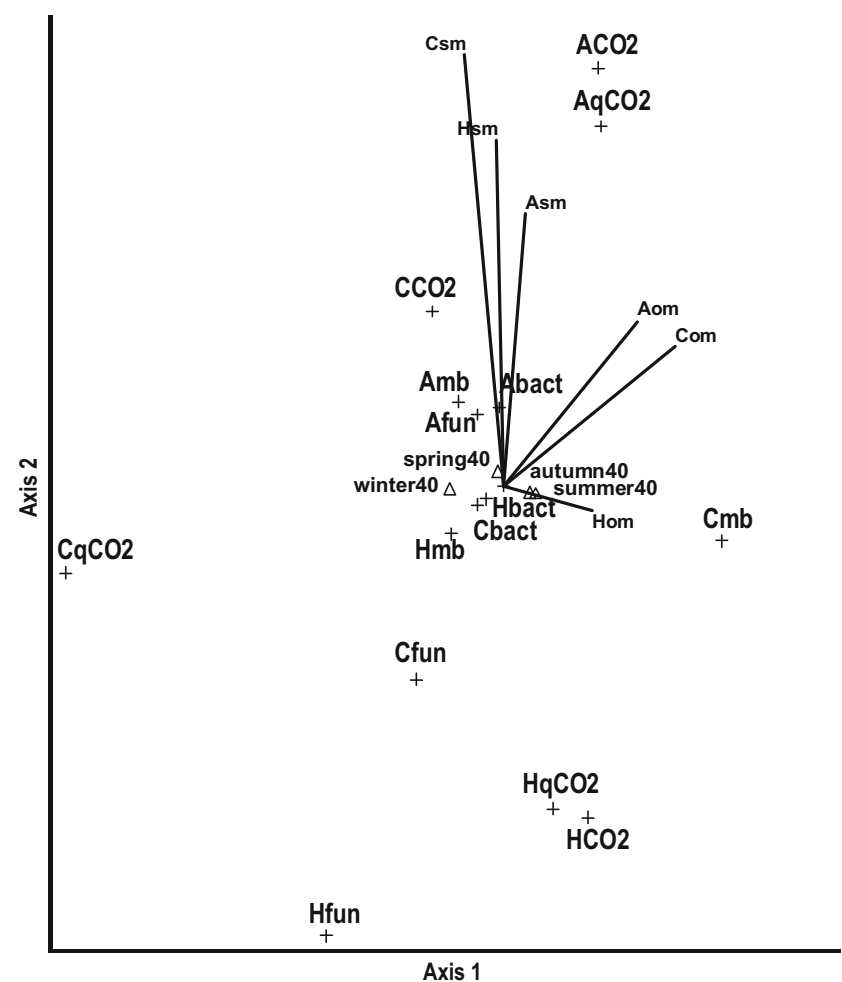

Figure 11 Reciprocal averaging analysis of microbial parameters in the control soil throughout the seasons at the $40-\mathrm{cm}$ depth. Each triangle represents a season (winter, spring, summer, and autumn); crosses represent microbial parameters - $m b$ microbial biomass, $\mathrm{CO}_{2}$ carbon dioxide, $q \mathrm{CO}_{2}$ quotient of $\mathrm{CO}_{2}$, fun fungal counts, bact bacterial counts. The capital letter before the parameter is the "treatment"-A A. halimus, H H. scoparia, $C$ control soil

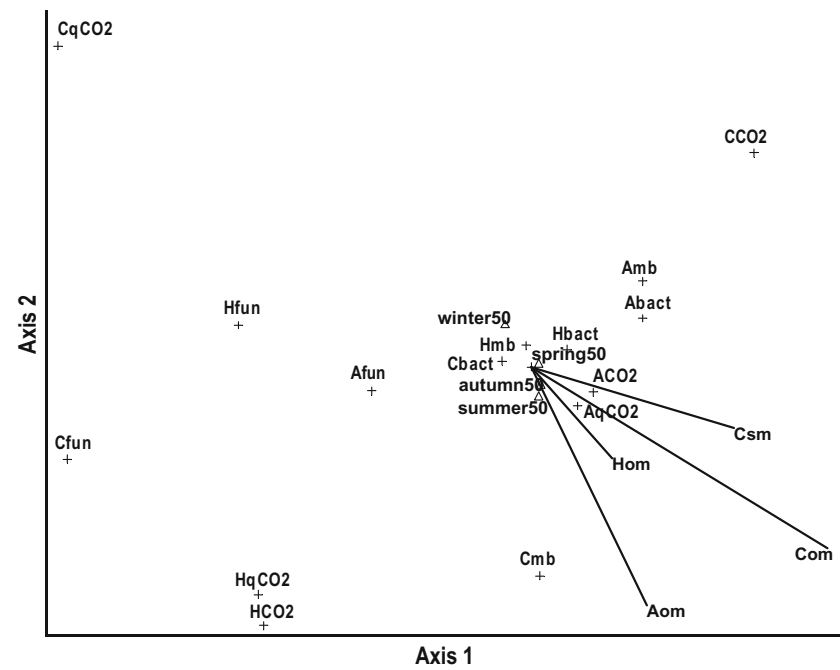

Figure 12 Reciprocal averaging analysis of microbial parameters in the control soil throughout the seasons at the $50-\mathrm{cm}$ depth. Each triangle represents a season (winter, spring, summer, and autumn); crosses represent microbial parameters $-m b$ microbial biomass, $\mathrm{CO}_{2}$ carbon dioxide, $q \mathrm{CO}_{2}$ quotient of $\mathrm{CO}_{2}$, fun fungal counts, bact bacterial counts. The capital letter before the parameter is the "treatment"-A A. halimus, H H. scoparia, C control soil 
increase in total bacteria count in the upper soil layers with increase in dryness both in the bare control samples and in the $H$. scoparia sampling sites. This elucidates the importance of both plant ecophysiological adaptation which differs from each other [11] and abiotic factors as among the main contributors to microbial community survival.

Soils in desert systems are dry for more than $90 \%$ of the year with very low water availability, leading to a lack of nutrients essential for biotic life functions [11, 38, 46]. Therefore, it has been suggested that perennial plant patches play an important role in localizing organic matter, soil moisture, and nutrients into patches beneath them, shaping "fertile islands" characterized by high $C_{\text {org }}$, increasing the "window activity" of biotic components, and greatly influencing the temporal and spatial (vertical) distribution of the above parameters [37, 38, 43].

Because of the relatively short activity period of soil biota in desert ecosystems, the need for a well-orchestrated response of soil biota to soil moisture, organic matter, and nitrogen availability is vital for their existence. Soils in the vicinity of plant canopies have been found to have significantly higher values of $C_{\text {org }}$, as found by Buyanovsky et al. [7], Kieft [20], and Yechieli et al. [50], leading to higher $C_{\text {mic }}$ and $\mathrm{CO}_{2}$ evolution in comparison to soils in the open spaces. This trend is not supported by the present data. The current study shows a consistently lower value in microbial and fungal CFUs in $A$. halimus vertical distribution and no consistency in $\mathrm{CO}_{2}$ evolution and $\mathrm{MB}$ where temporal and spatial changes occur throughout the study period. The importance of the "soil C triangle" (as termed by Anderson and Domsch [3, 4]), which includes $C_{\text {org }}, \mathrm{MB}$, and $\mathrm{CO}_{2}$ evolution, used to evaluate the status of soil stability in terms of microbial community and $C_{\mathrm{org}}$, was found to be greatly governed by plant ecophysiological adaptation.

The focus of the present study was to evaluate soil moisture availability, $C_{\text {org }}$, microbial and fungal CFUs, soil $\mathrm{MB}$, and soil $\mathrm{CO}_{2}$ evolution in a vertical section beneath two desert shrubs with distinct differences in their ecophysiological adaptations in an arid region in the Negev Desert. Although the shrub effect was observed to have a major outcome on microbial variables not only on a temporal but on a spatial (vertical) basis as well, this does very little to resolve the controversy regarding the difference between the shrubs.

Ordination of microbial parameters throughout the seasons showed that microbial functioning is more strongly governed by changes in soil moisture than soil organic matter, especially in the control soil. Soil moisture and organic matter played different roles for the determination of microbial functioning depending on plant species. Organic matter under each species determined microbial functioning as shown by CCA ordination. Correlations of microbial counts with soil moisture and organic matter increased throughout the seasons under both bushes and control soil. However, functioning of microorganisms showed differences associated with each plant: TSN was found to be positively correlated to these factors only under A. halimus. The changes in microorganism density and dynamics were found to be synchronized with water availability and used more nitrogen under this bush than under H. scoparia and control soil, probably because of higher nitrogen bioavailability in the litter under $A$. halimus. The plant factor may play a more significant role than just its shedding effect. The $\mathrm{qCO}_{2}$ under $A$. halimus and from the control soil was positively correlated to both soil moisture and organic matter, whereas the $\mathrm{qCO}_{2}$ under $H$. scoparia was positively correlated only to soil moisture. This suggests that organic matter under $H$. scoparia is not as easily metabolized by the microbial communities as that produced by $A$. halimus. Functioning of microorganisms under H. scoparia may be limited by the salt concentration of its litter, leaving few chances for organisms to metabolize it [23]. Thus, organic matter would tend to accumulate more under $H$. scoparia than under $A$. halimus because of the different velocity of degradation imposed by the salt content.

Seasonal patterns of microbial activity showed strong differences between plants and control soil throughout the soil layers. Control soil showed the cyclic pattern of microbial dependence on water availability expected in an uncovered place, whereas microbial activity moved along the water axes under A. halimus and along the organic matter under $H$. scoparia. In both cases, the differences were more remarkable in the 0 - to 10 -cm layer than in the deep layers. At the surface layer, evaporation is stronger than in the layers below, limiting the response of microorganisms to water availability [21, 49]. This limitation explains the correlation of microbial activity with water and organic matter during winter and spring under $A$. halimus and H. scoparia. However, the pattern of correlation of microbial activity to water availability and organic matter under each plant is very different (Figs. 3 and 4). Layers below $10 \mathrm{~cm}$ showed a decreasing correlation to both organic matter and water throughout the seasons as a consequence of the protective effect against desiccation provided by the $0-$ to $10-\mathrm{cm}$ layer and the shadow provided by plants (diminishing the variability of water and organic matter). The activity of the root zone may be another enhancing factor influencing microbial activity [29, 30, 49], which helps explain the differences between bushes as they have different strategies for survival in the case of drought $[21,49]$.

The CCA ordinations show that microbial functioning is more strongly influenced by changes in soil moisture than soil organic matter deposition at the control soil. Under shrubs, soil moisture and organic matter deposition has an 
almost equivalent importance for the determination of microbial functioning. As the ordinations of microbial communities under both bushes are different, it means that the kind of organic matter deposition provided by each plant plays a central role in microbial functioning. As can be seen in the ordinations by soil depths, the surface layers are more strongly influenced by water availability, whereas under the $30-\mathrm{cm}$ depth, the organic matter increases its importance. The fact that this effect is first noticed under $A$. halimus (at $30 \mathrm{~cm}$ ) and later under $H$. scoparia (at $50 \mathrm{~cm}$ ) stresses the importance of the root influence at these depths for these arido-active plants of the Negev and the importance of their physiological differences. These findings explain the protozoan diversity found, as noted by Rodríguez-Zaragoza et al. [29], for these depths. Under the 30 -cm depth, water availability may become more constant, as these layers are free of the air and sun desiccation factor where organic matter may become more important for microbial functioning. This may explain the relative independence of respiration quotient, respiration, and MB from soil moisture and organic matter below the $30-\mathrm{cm}$ depth. Even more, the differences found in this article can be because of a "plant" factor. However, there is also a difference between both bushes, meaning that the plant effect on microbial functioning is also species-specific.

These changes can also be taken as evidence that (1) microbial communities are continuously in transit between successional stages among changing microenvironments along soil layers, preventing them from reaching a definitive steady state and (2) the responses reflect ephemeral conditions because of temporal portioning of carbon and moisture availability. In addition, the results offer further evidence that plant effect on microbial functioning in desert soils is metabolic and not just physical and involves a closer relationship of the microbial community to each plant species than previously thought.

Open Access This article is distributed under the terms of the Creative Commons Attribution Noncommercial License which permits any noncommercial use, distribution, and reproduction in any medium, provided the original author(s) and source are credited.

\section{References}

1. Allen MF (1991) The ecology of mycorrhizae (Cambridge studies in ecology). Cambridge University Press, Cambridge

2. Anderson JPE, Domsch KH (1978) Physiological method for quantitative measurement of microbial biomass in soils. Soil Biol Biochem 10:215-221

3. Anderson TH, Domsch KH (1985) Determination of ecophysiological maintenance requirements of soil microorganisms in a dormant state. Biol Fertil Soils 1:81-89
4. Anderson TH, Domsch KH (1989) Ratios of microbial biomass carbon to total organic carbon in arable soils. Soil Biol Biochem 21:471-479

5. Anderson TH, Domsch KH (1993) The metabolic quotient for $\mathrm{CO}_{2}\left(\mathrm{qCO}_{2}\right)$ as a specific activity parameter to assess the effects of environmental conditions, such as $\mathrm{pH}$, on the microbial biomass of forest soils. Soil Biol Biochem 25:393-395

6. Berg MP, Bengtsson J (2007) Temporal and spatial variability in soil food web structure. Oikos 116:1789-1804

7. Buyanovsky G, Dicke M, Berwick P (1982) Soil environment and activity of soil microflora in the Negev Desert. J Arid Environ $5: 13-28$

8. Clark FE (1949) Soil microorganisms and plant roots. Adv Agron 1:241-288

9. Dan J, Yaalon DH, Koyumdji H, Raz Z (1972) The soil association map of Israel $(1: 1,000,000)$. Isr J Earth Sci 2:29-49

10. Danin A (1983) Desert vegetation of Israel and Sinai. Cana, Jerusalem

11. Evenari ME, Shanan L, Tadmor W (1982) The Negev: the challenge of a desert. Harvard University Press, Cambridge, MA

12. Fliessbach A, Sarig S, Steinberger Y (1994) Effects of water pulses and climatic conditions on microbial biomass kinetics and microbial activity in a yermosal of the central Negev. Arid Soil Res Rehabil 8:353-362

13. Franklin RB, Mills AL (2003) Multi-scale variation in spatial heterogeneity for microbial community structure in an eastern Virginia agricultural field. FEMS Microbiol Ecol 44:335-346

14. Frostegard A, Baath E (1996) The use of phospholipid fatty acid analysis to estimate bacterial and fungal biomass in soil. Biol Fertil Soils 22:59-65

15. Heinemayer O, Insam H, Kaiser EA, Walenzik G (1989) Soil microbial biomass and respiration measurements: an automated technique based on infrared gas analysis. Plant Soil 116:191-195

16. Houba VJG, Novozamsky I, Vittenbogaard J, Van Der Lee JJ (1987) Automatic determination of total soluble nitrogen in soil extracts. Landwirtsch Forsch 40:295-302

17. Insam H, Amor K, Renner M, Crepaz C (1996) Changes in functional abilities of the microbial community during composting of manure. Microb Ecol 31:77-87

18. Insam H, Parkinson D, Domsch KH (1989) Influence of macroclimate on soil microbial biomass. Soil Biol Biochem 21:211-221

19. Kaiser EA, Mueller T, Joergensen RG, Insam H, Heinemeyer O (1992) Evaluation of methods to estimate the soil microbial biomass and the relationship with soil texture and organic matter. Soil Biol Biochem 24:675-683

20. Kieft TL (1994) Grazing and plant-canopy effects on semiarid soil microbial biomass and respiration. Biol Fertil Soils 18:155-162

21. Kinsbursky RS, Degani R, Barness G, Steinberger Y (1990) Rootmicrobial population dynamics in a soil profile under the canopy of the desert shrub Zygophyllum dumosum. J Arid Environ 19:261-267

21. Krasilnikov NA (1958) Soil microorganism and higher plants. Academy of Sciences USSR, Moscow (in Russian)

23. Liang WJ, Mouratov S, Pinhasi-Adiv Y, Avigad P, Steinberger Y (2002) Seasonal variation in the nematode communities associated with two halophytes in a desert ecosystem. Pedobiologia 46:63-74

24. Ludwig JA, Reynolds JF (1988) Statistical ecology: a primer on methods and computing. Wiley, New York

25. McCune B, Meffod MJ (1999) PC-ORD. Multivariate analysis of ecological data, version 4. MjM Software Design, Gleneden Beach, OR, USA

26. Noy-Meir I (1973) Desert ecosystems: environment and producers. Ann Rev Ecolog Syst 4:25-51

27. Ou W, Liang WJ, Jiang Y, Li Q, Wen DZ (2005) Vertical distribution of soil nematodes under different land use types in an aquic brown soil. Pedobiologia 49:139-148 
28. Reynolds JF, Kemp PR, Ogle K, Fernandez RJ (2004) Modifying the 'pulse-reserve' paradigm for deserts of North America: precipitation pulses, soil water, and plant responses. Oecologia 141:194-210

29. Rodriguez-Zaragoza S, Mayzlish E, Steinberger Y (2005) Vertical distribution of the free-living amoeba population in soil under desert shrubs in the Negev Desert, Israel. Appl Environ Microbiol 71:2053-2060

30. Rodriguez-Zaragoza S, Steinberger Y (2004) Seasonal dynamics of amoebae in the root canopy of Zygophyllum dumosum in the Negev Desert, Israel. Pedobiologia 48:277-281

31. Rowell DL (1994) Soil science: methods and applications. Longman, London

32. S.F.A.S. (1995) Manual-San Plus analyzer. SKALAR Analytical, The Netherlands

33. Saetre P, Baath E (2000) Spatial variation and patterns of soil microbial community structure in a mixed spruce-birch stand. Soil Biol Biochem 32:909-917

34. Sarig S, Barness G, Steinberger Y (1994) Annual plant-growth and soil characteristics under desert halophyte canopy. Acta Oecol $15: 521-527$

35. Sarig S, Fliessbach A, Steinberger Y (1996) Microbial biomass reflects a nitrogen and phosphorous economy of halophytes grown in salty desert soil. Biol Fertil Soils 21:128-130

36. Sarig S, Steinberger Y (1994) Microbial biomass response to seasonal fluctuation in soil salinity under the canopy of desert halophytes. Soil Biol Biochem 26:1405-1408

37. Schlesinger WH, Reynolds JF, Cunningham GL, Huenneke LF, Jarrel WM, Virginia RA, Whitford WG (1990) Biological feedbacks in global desertification. Science 247:1043-1048

38. Shamir I, Steinberger Y (2007) Vertical distribution and activity of soil microbial population in a sandy desert ecosystem. Microb Ecol 53:340-347

39. Shukurov N, Pen-Mouratov S, Genzer N, Plakht J, Steinberger Y (2005) Distribution of soil microbial biomass and free-living nematode population in terrace chronosequences of MakhteshRamon crater. Arid Land Res Manage 19:197-213
40. Sokal RR, Rohlf FJ (1969) Biometry: principles, practices and statistics in biological research. Freeman, San Francisco, CA

41. Sokal RR, Rohlf FJ (1981) Biometry, principles, practices and statistics in biological research, 2nd edn. Freeman, San Francisco, CA

42. Steinberger Y, Shmida A, Whitford WG (1990) Decomposition along a rainfall gradient in the Judean Desert, Israel. Oecologia 82:322-324

43. Virginia RA, Jarrell WM, Whitford WG, Freckman DW (1992) Soil biota and soil properties in the surface rooting zone of mesquite (Prosopis glandulosa) in historical and recently desertified Chihuahuan Desert habitats. Biol Fertil Soils 14:90-98

44. Wardle DA (1992) A comparative assessment of factors which influence microbial biomass carbon and nitrogen levels in soil. Biol Rev Camb Philos Soc 67:321-358

45. Weisel Y (1973) Biology of halophytes. Academic, New York

46. Whitford WG (2002) Ecology of desert systems. Academic, New York, p 343

47. Whitford WG, Reynolds JF, Cunningham GL (1987) How desertification affects nitrogen limitations of primary production on Chihuahuan Desert watersheds. In: Aldon EF, Vincent GEG, Moir WH (eds) Strategies for classification and management of native vegetation for food production in Arid Zones, Rocky Mountain Forest and Range experiment station. Forest Service, U. S. Department of Agriculture, Fort Collins, CO, pp 143-153

48. Xie GH, Steinberger Y (2001) Temporal patterns of C and N under shrub canopy in a loessial soil desert ecosystem. Soil Biol Biochem 33:1371-1379

49. Xie GH, Steinberger Y (2005) Nitrogen and carbon dynamics under the canopy of sand dune shrubs in a desert ecosystem. Arid Land Res Manage 19:147-160

50. Yechieli A, Oren A, Yair A (1995) The effect of water distribution on bacterial numbers and microbial activity along a hill slope, northern Negev, Israel. Advances in Geoecology 28:193-207

51. Zohary M (1973) Geobotanical foundations of the Middle East, vol. 1. Fischer, Stuttgart, Germany

52. Zohary M (1973) Geobotanical foundations of the Middle East, vol. 2. Swets and Zeinlinger, Amsterdam, The Netherlands 